\title{
Anne Frank: The Commemoration of Individual Experiences of the Holocaust
}

\author{
Rudi Hartmann \\ University of Colorado Denver, Denver, USA
}

\begin{abstract}
Holocaust memorial sites rarely tell the story of individual fates but rather give attention to the main or larger population groups that were the focus of persecution and extermination during the Nazi Germany twelve years of terror in Europe 1933-45. This essay takes a closer look at one of the most remarkable exemptions of the prevailing memory culture at Holocaust memorials: the sites and events highlighting Anne Frank and her short life in troubled times. Over the past years millions of travelers from all over the world have shown a genuine interest in learning about the life world of their young heroine thus creating what has been termed Anne Frank Tourism. In 2014, 1.2 million people visited the Anne Frank House in Amsterdam: the museum and educational center, the place in hiding where she wrote her now famous and widely read diary. Several other sites connected to the life path of Anne Frank, from her birth place in Frankfurt to the Bergen-Belsen Concentration Camp where her life prematurely ended, have also become part of the mostly young tourists' search for Anne Frank's life and legacy. With the rising popularity of Anne Frank related sites the management of some of the locales has become more problematic which is discussed in the context of a several museums, centers and historic sites. On a more general note, it is argued here that in recent years the more group oriented commemoration practices at Holocaust sites have given way to a trend of putting individual faces to the victims of the Holocaust. It was, in particular, novels, films and TV productions about the Holocaust that emphasized individual life paths and events and enticed visitation to more personalized sites. Steven Spielberg's popular movie Schindler's List, for example, contributed to "Schindler tourism", a form of special interest tourism in Krakow. More and more Holocaust memorial sites have also started to honor outstanding individuals or small groups in resistance and opposition to Nazi Germany. Examples of this are the fighters of the 1943 uprising at the Sobibor death camp and the courageous student members of the "White Rose" in Munich who stood up to the powers of the time and were executed. In the concluding part the question will be raised of what is the proper approach in the representation of the fate of the victims of Nazi Germany: A personalized approach or a greater focus on an explanation of the ideology and policies behind the rule of terror which may contribute to the visitors' better understanding of a complex history?
\end{abstract}

Keywords: Anne Frank tourism, Holocaust memorials, individual experiences

\section{Introduction}

Memorials for the victims of Nazi Germany rarely feature the lives of individuals but rather give attention to the main or the larger population groups that were the focus of persecution and extermination. Most often,

Rudi Hartmann, Ph.D., Associate Professor, Department of Geography and Environmental Sciences, University of Colorado Denver. 
the agenda at Holocaust memorial sites is aimed at honoring the many lives that perished in a given historic situation or at a particular site and at paying tribute to the shear unaccountable number of human lives lost during twelve years of terror in Europe 1933-1945.

This article takes a closer look at one of the most remarkable exceptions of the prevailing memory culture at Holocaust memorials: the sites and events highlighting the persona of Anne Frank and her short life in troubled times. In the past years large numbers of travelers from different parts of the world have shown a genuine interest in following in the footsteps of their young heroine thus creating what has been termed Anne Frank Tourism. Since 2007, more than a million people annually have visited the Anne Frank House in Amsterdam, the museum and educational center including the place in hiding where she wrote her now famous and widely read diary. Several other locales connected to the life path of Anne Frank, from her birth place in Frankfurt in 1929 to the Bergen-Belsen concentration camp where her life prematurely ended in 1945, have become centers of attention and are well visited. Some of the museums and centers dedicated to Anne Frank have consistently seen increasing visitation numbers to the sites resulting in management problems which will be discussed here.

On a more general note, it is argued here that in recent years the more group oriented commemoration practices at Holocaust memorial sites have given way to a trend of putting individual faces to the victims of the Holocaust. It was, in particular, novels, films and TV series that emphasized individual life paths and events and enticed visitation to more personalized sites. Steven Spielberg's movie Schindler's list, for example, contributed to 'Schindler tourism', a form of special interest tourism in Krakow, Poland (Hartmann, 2016).

Over the years, more and more memorial sites for the victims of Nazi Germany have started to honor outstanding individuals or small groups in resistance and opposition to Nazi Germany. Examples for this trend are the memorial site at the Sobibor death camp remembering the 1943 uprising and an exhibit at the Munich University honoring the courageous student members of the "White Rose" who stood up to the powers of the time and were executed.

In the concluding part the more general question will be raised of what is the proper approach in the representation of the fate of the victims of Nazi Germany: A more personalized approach that may help the visitors to more closely identify with the perils individuals experienced during the years 1933-1945? Or a greater focus on an explanation of the ideology and policies behind the rule of terror which may contribute to the visitors' better understanding of a complex history? Which direction should Anne Frank Tourism as a form of Holocaust tourism follow (Hartmann, 2014, pp. 168-170)?

\section{Anne Frank Tourism}

Tourist activities motivated by a desire to learn more about young diarist Anne Frank and her legacies are focused on a number of places which are linked to her life path. Thus, Anne Frank tourism is largely but not exclusively limited to the seven stations of her life. These are the City of Frankfurt, in particular the Dornbusch city district, where Anne (Annelies Marie) Frank was born in 1929 and lived until 1933, then Aachen where she spent nine months at her grandmother Rosa Hollaender's house (1933/1934) before moving on to Amsterdam, to a first residence at Merwedeplein (1934-1942) and eventually to the Secret Annex after the family was forced to make the decision to go into hiding at 263 Prinsengracht (1942-1944) where Otto Frank's small business venture was housed in the front of the structure. The final three stops were forced moves and incarcerations at three types of Nazi concentration camps, first at the transit camp Westerbork in Drenthe 
Province of the eastern part of The Netherlands August 1944 to September 1944, then at the Auschwitz concentration camp near Krakow, Poland September 1944 to October 1944 and finally at the Bergen-Belsen concentration camp near Hannover, Germany where she and her sister Margot died in March 1945. Other places which are visited by Anne Frank fans and provide useful information about her life and legacy are located in Berlin, London, New York and Vienna, at later established "Anne Frank Centers". Some tourists follow in the footsteps of Anne Frank and visit all the stations of her life (see, for instance, the 50 page blog of Rockstroh 2013) while others go only to one or two sites.

\section{Bergen-Belsen}

All seven stations in Anne Frank's life are now accessible to tourists, with markers, museums and/or centers. Establishing the sites as memorial places has been a process over many years, often decades. The first site where the Anne Frank Tourism phenomenon was observed was at the former Bergen-Belsen concentration camp in the mid/late 1950s. The camp was liberated by British and Canadian troops in April 1945. For health reasons - thousands of prisoners died of a raging typhus epidemic in the early months of 1945 and were buried in nearby mass graves - the whole camp was demolished. Bergen-Belsen was one of the very early memorial sites for the Holocaust in Germany. It honored close to seventy thousand perished lives at a memorial site with a monument inaugurated in a ceremony in 1952 which saw high level participation of West German officials including President Theodor Heuss. With the German translation of Anne Frank's diary and a 1955 release of a highly popular paperback version the word about Anne's fate and death in Bergen-Belsen spread quickly. By the mid and late 1950s the Bergen-Belsen memorial site - now marked with a headstone for Margot and Anne Frank-became a pilgrimage site for the rapidly growing numbers of Anne Frank fans in Germany. Waves of Anne Frank admirers, mostly in form of groups and school classes, reached the memorial site. For the year 1959, at least ten thousand visitors were documented (Rosenfeld, 1991, pp. 259-263; Marcuse, 2001, pp. 200-203).

The headstone for Margot and Anne Frank has remained as a well-recognized part of the Bergen-Belsen concentration camp memorial site ever since, throughout the various phases of reconstruction, modernization and additions to the memorial and museum. The 2007 newly designed memorial site with a documentation center continues to pay special tribute to its most prominent victim, Anne Frank. Approximately 300,000 people annually come to Bergen-Belsen, a number which has been considered by the management of the site as the capacity limit for visitation.

\section{Amsterdam}

Arguably, the most salient destination for Anne Frank tourists is the Amsterdam place in hiding, the Secret Annex, which formed Anne's life world for more than two years, from July 1942 to August 1944. After the arrest of the group on August 8,1944, her diary books and other writings of hers were saved by secretary Miep Gies who eventually gave them to Otto Frank, the sole survivor of the eight persons in hiding; he became the editor and lifelong guardian of his daughter's works. An edited version of Anne Frank's diary entries was first released in 1947 (original Dutch title: Het Achterhuis) by a local Amsterdam publishing house (Frank, 1947). The historic site - soon known among many Amsterdam citizens "as a best known secret in town"-was saved from demolition in a public campaign 1955-1957. The Anne Frank House managed by the Anne Frank Stichtung foundation opened to the public as a small museum in 1960. Within a decade the number of visitors went from ten thousand during the first year to close to two hundred thousand in 1970. Visitation continued to 
climb rapidly throughout the 1970s and 1980s and surpassed six hundred thousand. Thus, the small site was plagued by severe capacity problems and a project "The Maintenance and Future of the Anne Frank House" was implemented, with a complete restructuring of the museum complex. After careful preservation of the Secret Annex, a spatially confined area of the structure, and the restoration of the front of the house as well as the inclusion of several neighboring buildings the Anne Frank House became a large educational center and leading tourist destination in Amsterdam. In 2007, annual visitation surpassed one million. One of the bottlenecks in the visitation of the site is the Secret Annex with a capacity limit of four hundred persons per hour (Boswijk, Peelen, and Olthof, 2012). Despite extended opening hours throughout the year and convenient Internet information about the hours of when to best visit the museum, long lines tend to form outside the building, often around or beyond the whole city block, with now 1.2 million visitors (2014) waiting to see "Anne's place".

The Anne Frank House serves three main functions. Besides being a memorial site and a place of learning along Anne's humanistic ideals, it represents a literary landscape well loved by millions of Anne Frank admirers. Since 2010 it is accessible in 3D as a "Secret Annex Online" journey on the Internet. The highly professionally crafted virtual reality version of the house, with a narrating "Anne Frank" voice, was visited by approximately 2.5 million during the first three years (Hartmann, 2013).

It should also be mentioned that the Anne Frank House has made great efforts in collaborating with other Amsterdam museums and institutions which cover aspects of Amsterdam's years of Nazi Germany occupation. Among others, the Anne Frank House has worked with the local Jewish History Museum in a special exhibit, "Children and the Holocaust". In 2006, the Anne Frank House developed a themed neighborhood walk "Persecution and Resistance in Amsterdam 1940-1945", jointly with the Verzets (Dutch Resistance) Museum. Subsequently, several self-guided neighborhood walks or organized bicycle ride tours in Jewish Amsterdam were offered. The management of the Anne Frank House also realized that most of the young admirers of Anne Frank use social media. Thus, they offered more web site information and contact possibilities. In April 2012, a new mobile application, "Anne's Amsterdam", became available. It allows the users to see personal photographs and historic clippings which highlight those places in Amsterdam which had direct or indirect meaning in Anne's life (Hartmann, 2013).

In 2005, the Merwedeplein apartment complex in South Amsterdam which included the first residence of the Frank Family (1933/34-1942) was adorned with an Anne Frank statue. It was the second public sculpture designed in the honor of Anne, with the first one erected in 1977 on the Westermarket square, in close proximity to the House. Over the years it has become a landmark and highly photographed object well recognized by Amsterdam tourists.

While the visit to the Anne Frank House, the "House with a Story" (Westra, 2000), provides many details about the eight people in hiding and their helpers little is said about the betrayal leading to the arrest of the group. There is continued interest in (and some fascination about) what may have happened in August 1944. Several inquiries in 1947/1948 and in 1964 did not lead to a conviction. Initial accusations against a warehouse worker, the main suspect for the betrayal of the group at 263 Prinsengracht, could not be proven. In later years, new theories about the potential culprit and/or the circumstances of the betrayal have emerged. None of them turned out to be conclusive or offered a satisfying explanation. In various ways, though, all the continued discussions of the theme were able to shed more light on the historic situation in Amsterdam during the five long years of Nazi German occupation 1940-1945 and the enormous difficulties Jews and other persecuted 
persons who went underground had to stay undetected. After decades of search for the person who took the money for the betrayal of the group, the Anne Frank House and helper Miep Gies had to resign themselves to a "We shall never know" (Mueller, 1998; Lee, 1999, 2002; Netherlands Institute for War Documentation, 2003; Gies \& Gold, 1987, 2009; Hartmann, 2013).

The unsolved circumstances of the betrayal represent a distinct feature in the public construction of the Anne Frank narrative. More unanswered questions have remained regarding her life after the arrest—all contributing to a mystique surrounding Anne Frank's fate. Her experiences during the transports to and from the three camps and her stays at Westerbork, Auschwitz and Bergen-Belsen are still largely shrouded in mystery - in particular, when compared to the detailed descriptions we have from the time in hiding. Speculations about what might have happened to Anne continue to abound, and reports regularly reach the media about new findings, for instance, as to when and how she died. Now, some experts assume that Anne and Margot Frank might have died earlier, in February 1945 (Anne Frank House Museum, 2015). Advanced research efforts at the burial sites have been met with resistance by the management of the Bergen-Belsen memorial site. So far, they have refused to allow the digging up of the mass graves to get more conclusive evidence (Hall, 2015; Nsubuga, 2015). Subsequently, the discourse over a valid Anne Frank story has raised the interest in some of the places connected to her life path.

Several writers, researchers and close friends of Anne Frank have tried to reconstruct her experiences during the last months of her life. Probably, the most substantiated and coherent effort was made by Dutch journalist Willy Lindwer by interviewing seven women who knew Anne Frank from Amsterdam and shared similar experiences in Westerbork and/or Auschwitz and/or Bergen-Belsen. Lindwer's documentary film tells what these Holocaust survivors witnessed including their stories of the more or less brief encounters they had with Anne at these places and their descriptions of the horrific situation Anne found herself in at age fifteen. Lindwer's film The last seven months of Anne Frank, also published in book form (Lindwer, 1992), won an Emmy award.

\section{Westerbork}

What we know for sure is that the eight people arrested in Amsterdam were deported to Westerbork in the Eastern Province of Drenthe on August 8, 1944. Since they were detected in hiding they had to live in the punishment block of Kamp Westerbork, a transit camp for more than one hundred thousand Dutch Jews and several hundred Sinti and Roma. Once a week trains left for camps farther East, mostly to the death camps of Auschwitz and Sobibor. The Frank Family was put on a train to Auschwitz on September 3, 1944 which turned out to be last deportation to Auschwitz from Westerbork.

Kamp Westerbork was liberated by Canadian troops on April 12, 1945. After serving as a housing area for Dutch nationals from the East Indies (Indonesia) and for refugees from the Maluku Islands the former transit camp was demolished in the 1970s. In 1983, it was re-established as a memorial site: the Kamp Westerbork Remembrance Center, with museum exhibits and archives. The former camp grounds two miles from the museum, with several memorials, are accessible by shuttle bus, on foot and by bicycle. Seventy to eighty thousand people visit the relatively remote site annually.

Not surprisingly, Anne Frank, her family and the four other people in hiding are featured repeatedly at the memorial site and museum. The punishment barrack where they had to live was reconstructed. The museum exhibits also show the four names of the Frank Family on the list of deportees on the September3, 1944 train. 
In one of the Camp Westerbork publications with focus on children in the camp Anne Frank's persona is highlighted. The Kamp Westerbork Herinnerungszentrum has national importance in the recognition of the Dutch victims of Nazi Germany. It is here that tourists in the footsteps of Anne Frank learn about the broader context of lost Jewish community lives in The Netherlands, with $75 \%$ of Dutch Jews ultimately perishing in the Holocaust.

\section{Auschwitz}

The Frank Family and group of eight in hiding were divided upon arrival in Auschwitz on September 5, 1944. The male and female group members were separated which meant that father Otto Frank would never see his wife and daughters again. While mother Edith Frank fell ill and died in Auschwitz-Birkenau, her two daughters Margot and Anne were put on a train after six weeks leaving Auschwitz to their final destination, Bergen-Belsen. It was only father Otto Frank who would live to see the liberation of the camp by the Red Army on January 27, 1945. More than 1.1 million persons, the large majority Jews, died in Auschwitz I (Main Camp), Auschwitz-Birkenau and at the Auschwitz-Monowitz subsidiary camps. Given the magnitude of the mass murder committed at this large complex and the sheer number of perished lives it is remarkable that Anne Frank has become one of the individual faces of the Holocaust featured at the Memorial and Museum Auschwitz-Birkenau. Her books are sold at the museum store, her story is told in the Auschwitz Dutch Pavilion renovated and updated in 2009. Auschwitz was declared a UNESCO World Heritage Site in 1979 and currently receives 1.3 million visitors annually.

There are two main reasons which account for the changes in the commemoration practices at Auschwitz allowing the management of the memorial to highlight Anne Frank's fate in recent years. First, the Auschwitz memorial site became more easily accessible to Western tourists after the fall of the 'Iron Curtain' in 1990/91. After a dramatic increase in visitation and a substantially changed composition of the visitors coming to a greater degree from the neighboring Western European countries as well as the U.S. and Canada concessions had to be made by the management to the presentation of the exhibit materials. Secondly, a shift in the mission of the memorial site occurred, from a heavy emphasis on "the martyrdom of the Polish people" to a site now largely honoring the victims of the Holocaust. The trend to "de-Judaize" the historic site in the 1970s, 1980s and early 1990s guided by a museum management under the influence of the Communist Party and the Polish Catholic Church (see, for instance, Charlesworth, 1994) saw a reversal. By the early 2000s, Auschwitz has become the leading Holocaust memorial worldwide thus also eclipsing Dachau as a symbol of Nazi atrocities (Marcuse, 2005, p. 118).

\section{Aachen}

As shown above for Auschwitz's late acceptance of the young diarist, two other stations of the life path of Anne Frank, Aachen and Frankfurt, were relative latecomers in her recognition. Here, different reasons prevailed for neglecting the personal legacy of Anne Frank for an extended time period. It was not until the 1990s and 2000s that the presence of Anne Frank in both cities was appreciated in locally distinct ways. New developments in the commemoration practices of the Holocaust in Germany-beyond "the coming to terms with the past" approach of Vergangenheitsbewaeltigung (see, for instance, Rosenfeld, 1991, pp. 263-264) - reached younger generations and had an impact in the two cities over time.

It was through a creative art project launched by Cologne artist Guenther Demnig in 1995 that many cities in Germany and European-wide found appropriate in remembering former citizens lost during the Nazi years. 
Demnig had the idea of placing commemorative stones-stumbling blocks ("Stolpersteine") in the form of cobble stone size brass memorials - in front of the final home of residents who were deported and murdered during the years 1933-1945. Meanwhile more than 48,000 of these stumbling blocks have been installed in about 1,000 German/European cities. This movement also reached Frankfurt and Aachen. In the latter city, 17 stumbling blocks were laid in 2008/2009, with great citizen participation (and enthusiasm) including many local high school students. In front of Pastorplatz 1, the former residence of Anne Frank's Grandmother Rosa Hollaender, three stumbling blocks were placed, in the honor of Rosa Hollaender, of Margot Frank and of Anne Frank, with basic information about their lives and fate during the Nazi years of terror. Two years before (2007), another marker was placed there: a more traditional memorial plaque which focused on Anne Frank and gave information about her stay at her grandmother's home. Both forms of memorial markers at the former Rosa Hollaender home near a public park are now a widely recognized landmark in the City of Aachen.

\section{Frankfurt}

In the case of Frankfurt another type of history project was crucial in more distinctly remembering Anne Frank. Certainly, in 1960 the City of Frankfurt had named one of their middle schools in honor of the now famous former resident. However, there was no information center or museum in town that highlighted her legacy. The situation changed with a "Spurensuche" project in the 1993/94, the "search for (lost) traces" for the artifacts/socio-facts from the years 1933-1945. This type of "Erinnerungsarbeit", a more active form of "memorial work", has been particularly appealing to the younger generation. It has to be mentioned here that physical reminders of the autocratic rule of the National Socialist Party in Germany such as the barracks of concentration camps were frequently removed from the public eye after they were used/abused as temporary housing areas for displaced persons and ethnic German refugees in the 1950s (Marcuse, 2010). During the height of the "Cold War" (early 1950s to the mid 1960s) the political agenda in West Germany saw major shifts allowing former members of the Nazi Party to become integrated in the government agencies again. Thus, dealing with the past was no longer considered a priority. It took another generation of teachers and democratic leaders to overcome the reluctance to "dig into" a controversial historic chapter of a local community. The search for (lost) traces project in the Dornbusch city district in Frankfurt saw about two hundred people - among them many teenagers - actively reconstructing the world of the Frank Family who had lived there 1927-1933. The result of the project was the foundation of a "Youth Meeting Center Anne Frank (Jugend Begegnungsstaette Anne Frank)" which was opened at a summer fest in 1997 and eventually received the financial support of the City of Frankfurt. The new local institution offers guided tours of an Anne Frank exhibit "Anne Frank-Ein Maedchen aus Deutschland" (Anne Frank-A Girl from Germany). The Center is also used for many cultural events and seminars embracing Anne Frank's values and ideals (Jugendbegegnungsstaette, 2004). Two neighborhood buildings were of particular interest to the local community: Anne Frank's 1929 birth place at the house on Marbachweg 307, now with a large marker displaying a photo of the Frank girls, and the house on Ganghoferstrasse 24, with a plaque and an Anne Frank quotation from her diary reminding the public of the other Dornbusch home of the Frank Family (1931-1933).

This neighborhood initiative has had continued and wider impacts on city life in Frankfurt. Local historians worked on a Frank - Stern family tree reaching back to 1600s when ancestors of Anne Frank lived in the Frankfurt Jewish Ghetto ("Judengasse") with a map showing all the major moves and connections the family had during several centuries of residence in Frankfurt (Rahlwes \& Wawra, 2014). In 2015, the City 
chose as its suggested annual reading ("Frankfurt liest/Frankfurt reads") a book about the Frank Family: Miriam Pressler's "Gruesse and Kuesse an alle - Die Geschichte der Familie von Anne Frank" ("Treasures from the Attic: Anne Frank's Family" in English).

Anne Frank's legacy in Frankfurt is still evolving. The Anne Frank Education Center (new name and mission of the former Youth Meeting Center since 2012) has the plan to expand its current exhibit to the second floor in 2016, and the Frankfurt Jewish Museum which started a Frank Family Center (with donations and assistance of the influential Anne Frank Fonds organization) has decided to feature the family in a new section of the museum in coming years. A more comprehensive re-integration of the Frank Family into the fabric of Frankfurt community life seems to be on the wider horizon. All this is about to create a new anchor for Anne Frank Tourism in Frankfurt.

The Anne Frank House and the Anne Frank Fonds: Complicated Relationships Over the Task of Safeguarding Anne Frank's Legacy

Two organizations have a greater role and responsibility for protecting Anne Frank's legacy and indirectly for the formulation of policies affecting Anne Frank Tourism: the Anne Frank Stichting foundation in charge of the Anne Frank House in Amsterdam (established in 1957 by Otto Frank) and the Anne Frank Fonds in Basel, Switzerland. The latter organization was also established by Otto Frank (in 1963). After his liberation from the Auschwitz Concentration Camp he returned to Amsterdam in the summer of 1945 and lived temporarily at the home of Miep and Jan Gies. For several years he continued his small business operations at 263 Prinsengracht. In 1947, he initiated and guided the Dutch publication of his daughter Anne's diary as well as translations into German, French and English by 1952. In 1953, he moved with his second wife Elfriede 'Fritzi' Geiringer, a widowed Auschwitz survivor, to Basel where his mother Alice Stern Frank still lived as well as his sister Helene 'Leni' Frank Elias with her family. While Otto Frank was highly involved in saving the house on 263 Prinsengracht with fellow Amsterdam citizens in 1955-1957 and succeeded in the opening of the Secret Annex as a small historic museum in 1960, the international sales of "Anne Frank: The Diary of a Young Girl” (Frank, 1952) took off. Anne's diary and life in hiding received tremendous public exposure, first with a Broadway drama (1955) and then a movie (1959). Both productions were very successful and received Tony Awards and Oscars respectively. Thus, another organization for protecting the copyright of the book and for dealing with the permission of associated rights was needed. With this purpose in mind, Otto and 'Fritzi' Frank established the Anne Frank Fonds in 1963 in Basel. The income from the royalties was used to fund projects. Over the years, many important contributions to the legacy of Anne Frank have been made by channeling money into beneficial funding activities. Anne Frank's diary has been published in more than sixty languages and a multitude of artistic applications of the diary have been proposed and most often approved by the Anne Frank Fonds. In the last two decades Anne Frank's oeuvre and her stature as a leading twentieth century author have been strengthened by additional editions, most of all a "definitive edition" including originally omitted pages and other writings. Some reviewers and special exhibits have portrayed Anne Frank as a beyond her age mature thinker, e.g., in a 2003 Washington, D.C. special exhibit "Anne Frank the Writer: An Unfinished Story" facilitated by the Anne Frank House (Frank, 1995; Rosenblatt, 1999; Netherlands Institute for War Documentation, 2003; United Holocaust Memorial Museum, 2003; Becker, 2003).

The mission, agenda and actual achievements made by the Anne Frank Stichting foundation in Amsterdam are quite different from the work of the Basel Anne Frank Fonds. The mission of the Amsterdam non-profit 
organization includes the task of preserving Anne Frank's hiding place and her diaries and of spreading the message of Anne Frank's life and ideals worldwide (www.annefrank.org/). Since the large majority of the visitors come from many different countries outside The Netherlands, the Anne Frank House has developed an intercultural perspective in the dissemination of information early on and fostered an international network in the representation of Anne Frank issues and themes over the years. Among others, they helped to establish "Anne Frank Centers" in New York, London, Berlin and Vienna as well as initiated and/or co-organized traveling exhibitions ("Anne Frank-A History for Today", "Anne Frank in the World Today”) in more than one hundred cities. Currently, they have youthful, engaged "Anne Frank Ambassadors" in 44 countries worldwide. Under the long-time leadership of Executive Director Hans Westra (1974-2010) collaboration both with other Holocaust Memorial organizations abroad and local Amsterdam institutions developed. The Anne Frank House has not only become a widely recognized institution in the field of Holocaust education, but is also known for its research efforts, archives and collections. In 2009, the Anne Frank House received the original diaries on a permanent loan from the Netherlands Institute of War Documentation. The Anne Frank Stichting employs about one hundred staff members and has a sizable budget which is published annually. Income for the foundation rests almost solely on entrance fees to the House and on book sales.

After Otto Frank passed away in 1980, a more competitive and at times contentious relationship between the two organizations evolved. Some of the disagreements and conflicts ended up in court. A first trial over the trademark of the Anne Frank Name was decided in the favor of the Anne Frank House in the late 1990s. A 2007 agreement reached between Bernard "Buddy" Elias, cousin of Anne Frank and then President of the Anne Frank Fonds, and CEO Hans Westra formed the basis for the transfer of the Swiss family archives to the Anne Frank House on long-term loan. In 2011, the agreement was rescinded by the Anne Frank Fonds, a decision contested by the Anne Frank House but confirmed in court in 2013. The family archives in question were eventually moved to Frankfurt, where an inventory has been conducted by the Frankfurt Jewish Museum for the further development of a Frank Family Center. A third major legal conflict might arise from the Anne Frank Fonds decision to take measures to avoid losing the copyright to Anne Frank's diary. After seventy years, the Anne Frank Fonds' copyright will expire in most European countries (including The Netherlands). It would enter the public domain in 2016 - unless the courts confirm a legal move by the Anne Frank Fonds to include editor Otto Frank now as a co-author (Pearl, 1997; Fox, 2015). This would allow the Anne Frank Fonds to retain the copyrights till 2050. Ultimately, the rivalry between the two organizations is rooted in a divergent perspective on who rightfully "owns" Anne Frank.

\section{Criticism: Is Anne Frank Jewish Enough?}

Members from the Anne Frank Fonds Board and President Bernard "Buddy" Elias repeatedly raised the question: Is the Anne Frank persona depicted in the exhibits at the Anne Frank House as "Jewish" enough and has the Amsterdam non-profit organization deliberately sought to "de-Judaize" her?

There is a long history of this controversy and argument which has been leveled against the Amsterdam management of the House, even against Otto Frank. It flared up at the occasion of a planned adaptation of the diary for a Broadway drama. Otto Frank and his theater consultant Lillian Hellman preferred Frances Goodrich and Albert Hackett's version over the one proposed by Meyer Levin in 1952/53. Levin argued the real reason for the rejection was that his dramatization was considered "too Jewish". Originally coming from Eastern 
Europe and being an Orthodox Jew, he resented the way he was treated by the more pronounced secular German Jews, Frank and Hellman. The case was settled in court and indirectly on stage - as Goodrich and Hackett went on to win a Pulitzer Prize (Netherlands Institute for War Documentation, 2003).

Later conflicts over the Anne Frank trademark decision in the 1990s saw another review of the perceived de-contextualization and de-Judaization of the young diarist in Amsterdam. The Anne Frank Fonds also complained about the lack of Jewish employees among the many Anne Frank House staff members. More recently, the disagreement over Anne Frank's Jewishness moved into the philosophical debate of how to commemorate victims of the Holocaust. Yves Kugelmann, board member and spokesperson of the Anne Frank Fonds (as well as editor of Jewish newspapers in Switzerland and Germany), argued that "in the Christian tradition you make dead people into icons, whereas in the Jewish tradition you focus on books and other written evidence" (Kugelmann in Ivry, 2015). It is, in particular, the iconic Anne Frank figure in the "shrine-like atmosphere at the Amsterdam Anne Frank House" that has been criticized in Basel:

What is made out of the story of Anne Frank is that she lived in an annex, which is not representative of being in hiding or being a wartime refugee, and this story was made into an icon of the general experience of Holocaust survivors...I am not criticizing Anne Frank, but how society takes her out of context and makes her the quintessential Holocaust victim, which she is really not. (Kugelmann in Ivry, 2015).

Nevertheless, "Anne", a new play supported and partially financed by the Anne Frank Fonds, takes the same route of center-staging Anne Frank. The show is a fictional answer to the speculative question "What if Anne Frank had lived?" (Lebovic, 2014). Eva Geiringer Schloss, step-sister of Anne Frank (both were born in 1929, both were living in the Merwedeplein apartment complex) survived Auschwitz and continued to live in Amsterdam before getting married in the UK. Schloss has a more critical view of the current agenda of the Anne Frank Fonds. She believes that (her stepfather) Otto Frank did not see a role for the Anne Frank Fonds for exhibitions, plays and political action. "(Otto) Frank did not believe that Anne's story should be presented specifically as that of a Jewish girl” (Ivry, 2015).

\section{"Beyond Anne Frank": A (Dutch) National Holocaust Museum and Memorial Wall in the Planning}

While the City of Amsterdam takes great pride in having the historic site where Anne Frank wrote her diary and in supporting the maintenance and management of the Anne Frank House, there is also general agreement among the citizens that the local and national story of the Holocaust should be told in a broader way that honors all the victims. Efforts have been made to go "beyond Anne Frank" and her widely known narrative. Many more people were in hiding during the five years of Nazi Germany occupation with some surviving, others being captured and deported. Almost three quarters of the 135,000 Jews living in The Netherlands found their death in Auschwitz, Sobibor or Bergen-Belsen. The Dutch rate of victimization was the highest among Jews in Central and Western European countries.

To date, several memorials have been established in the old Jewish Quarter of Amsterdam including at the Hollandsche Schouwburg, the main deportation center for Amsterdam Jews, with the known names of people who went through this place on their way to Westerbork. Nearby is the site of the recently opened (Dutch) National Holocaust Museum. In addition, the Dutch Auschwitz Committee plans to prepare a Memorial Wall honoring the 102,000 Dutch victims of the Holocaust. After 10 years of negotiation with the City a site has been secured. 
The Memorial Wall will invite relatives and friends of the victims as well as visitors to Amsterdam to find a particular name as an active way of commemoration. Many of the visitors will most likely search for some of the more widely known Dutch victims including the name of Anne Frank.

\section{A Greater Focus on Individual Experiences of the Holocaust}

Since the 1980s/1990s, the presentation of individual experiences of the Holocaust has become a more common theme at memorial sites for the victims of Nazi Germany. The public has accepted the usefulness of individual close-ups. In the words of historian James Young, Anne Frank's story is "a window to the Holocaust" (1999).

During the 1950s/1960s/1970s the focus in the museum exhibits of memorial sites was on the group experience, largely from the perspective of the political prisoners at the concentration camps as can be reconstructed for Dachau (in West Germany) and in Buchenwald (in East Germany). A revamped and extended exhibit at Dachau (2005) gives more space to individual experiences from all the major prisoner groups. The most recent exhibit at the nearby execution area at Hebertshausen, where more than 4,000 Soviet prisoners were shot, features several individual life paths of the victims. In a new approach, several Russian victims are individually honored at this memorial site. In Buchenwald, research efforts were made with, among others, a special "Spurensuche" (search for lost traces) project for the prison cell of Dietrich Bonhoeffer. The life story of this pastor in opposition to the Third Reich is told at the re-modeled memorial site.

There are many more examples featuring some of the more notable prisoners at memorial sites, such as in the new exhibits at the "Topography of Terror" site in Berlin (former GESTAPO headquarters). In the new Esterwegen concentration camp memorial exhibits for the early camps in Northeast Germany (1933-1936) composer Wolfgang Langhoff is featured. As a prisoner he was instrumental for a cultural camp event ending in the now famous Moorsoldaten-Lied ("We are the peat bog soldiers-Song"), a hymn later forbidden at concentration camps but widely sung all over Europe. In 2007, a Mollheim Memorial was established on the grounds of the Frankfurt University in the honor of Norbert Wollheim, a prisoner at Auschwitz-Monowitz who took on the IG Farben chemical corporation (with a plant and the forced and fatal uses of prisoners there) in a law suit.

One of the reasons for this trend are the featured individuals in many Holocaust films shown in the movies or as TV productions. Holocaust films have become a new genre which are quite popular in the media, from the 1978 "Holocaust" TV mini series to the recently released Auschwitz film "Son of Saul" (December 2015). In several cases movie productions were able to initiate tourism to the sites where they were filmed. Probably, the best example for this is Steven Spielberg's "Schindler's List" (1993) which resulted in a form of special interest tourism in Krakow, Poland: "Schindler tourism" (Ashworth, 2002).

Other major themes in the representation of the Holocaust experience are uprisings, direct confrontations and open resistance. Over the past two decades the public has given special attention to the relatively rare event of prisoners or citizens revolting against the Nazi powers such as SS wardens or the political police. Memorials and special exhibits honor these individuals who had the courage to speak up and take action. Probably, the most outstanding memorial is in Warsaw, for the thirteen thousand resistance fighters who died during the four week period of the Warsaw Ghetto uprising April 19-May 16, 1943. Two other examples are the uprising at the Sobibor extermination camp and the White Rose ("Weisse Rose") student group at the Munich University. During a prisoner revolt on October 14, 1943 about 300 persons were able to escape from the Sobibor camp. 
The majority of the escapees were captured again and executed. Fifty-seven people survived and were liberated by the advancing Red Army in late 1944. One of the results of the uprising was an accelerated closure of the camp in October 1943. Thomas Blatt, one of the survivors, wrote a memoir "Sobibor: The forgotten Revolt" which became a basis for a documentary film "Escape from Sobibor". In 2003 a monument for the fighters was included in the restructured Sobibor memorial grounds. The Munich White Rose resistance group has also gained recognition, with several novels, films and a special exhibit at the Munich University. The siblings Hans and Sophie Scholl, two of the students who produced anti-Nazi leaflets and distributed them right in the university building have become idols for a younger generation in Germany. What makes these and other individuals so memorable is that they kept their moral compass in imperiled times knowing that they could be and would be executed (Hartmann, 2016).

\section{Conclusions}

What is the most appropriate way to honor the victims of Nazi Germany? Should the narrative at the museums be more focused on the individual experiences of the Holocaust which allow visitors to better identify with the victims or should an explanation of the ideology and policies behind the rule of Nazi terror dominate which may contribute to the visitors' better understanding of a complex history? In most cases, Holocaust memorial sites have chosen to display both themes and to follow both pedagogical directions. The early Anne Frank House exhibits gave more attention to the personal story of Anne Frank and of her family and less to the changing social and political situation in Germany and The Netherlands-largely due to the lack of space at the House until the 1970s/1980s. Expansions of the exhibit space in the museum building eventually allowed more coverage of the developments in 19th and 20th century history. Over the past years the museum exhibits at the Anne Frank House have been continuously reviewed, reworked and updated to display newly available information.

In closing it should be mentioned that the Anne Frank House has become an educational center with a pioneering pedagogical agenda. At the end of the formal displays along the museum route, the mostly young visitors to the House are invited to reflect on current local and regional crises because of existing racial, ethnic and religious stereotypes, misperceptions and inequalities in the world. Intentionally and in intriguing ways, the humanistic ideals of Anne Frank are put to work. Visitors are to leave "Anne's place" with a newly gained consciousness and a shared quest for peace. It is Otto Frank's legacy to integrate his daughters' values as expressed so persuasively in parts of her diary as a framework for work at the Anne Frank House Stichting foundation and the Anne Frank Fonds. While both organizations may argue on many issues, it is obvious that on this agenda they can agree. Since the year 2000, the Anne Frank Fonds subsidizes annually organized Anne Frank Peace Days in Bergen-Belsen. Thus, Anne Frank tourism has a normative side, reminding people in the footsteps of Anne Frank what kind of lessons they should draw from her life.

\section{References}

Anne Frank House Museum. (2015). Anne Frank House museum: Jewish diarist likely died earlier. Retrieved from http://www.aol.com/article/2015/03/31/anne-frank-house-museum-jewish-diarist-likely-died-earlier/

Anne Frank House. (2015). Anne Frank House: Organisation and mission statement. Retrieved from http://www.annefrank.org/en/sitewide/Organisation/Organisation/

Ashworth, G. J. (2002). Holocaust tourism: The experience of Krakow-Kazimierz. International Research in Geographical and Environmental Education, 11(4), 363-367. 
Boswijk, A., Peelen, E., \& Olthof, S. (2012). Economy of experiences.3.7 case study-Anne Frank House. Bilthoven, Netherlands: European Centre for the Experience Economy.

Carajal, D. (2015). Anne Frank Gains "Co-Author" in Copyright Move. New York Times (p. A3).

Charlesworth, A. (1994). Contested places of memory: The case of Auschwitz. Environment and Planning D: Society and Space, 12(5), 579-593.

Fox, M. (2015). Buddy Elias, First Cousin of Anne Frank, Dies at 89. New York Times (p. A20).

Frank, A. (1947). Het Achterhuis. Dagboekbrieven Van 14 Juni 1942 - 1 Augustus 1944 (The Annex of the House: Diary Entries June 14, 1942 - August 1, 1944). Amsterdam: De Contactboekerij.

Gies, M., \& Gold, A. (1987). Anne Frank remembered: The story of the woman who helped to hide the Frank Family. New York: Simon and Schuster.

Gies, M., \& Gold, A. (2009). Afterword: My 100th birthday in Anne Frank remembered (pp. 253-264). New York: Simon and Schuster.

Graber, L. (1995). An obsession with Anne Frank: Meyer Levin and the diary. Berkeley, CA: University of California Press.

Hall, A. (2015). Mass grave may hold Anne Frank: Holocaust survivors help pinpoint new site near concentration camp which may contain diarist's remains. Daily Mail, 12 April 2015.

Hartmann, R. (2013). The Anne Frank House in Amsterdam: A museum and literary landscape goes virtual reality. Journalism and Mass Communication, 3(10), 625-644.

Hartmann, R. (2014). Dark tourism, thanatourism, and dissonance in heritage tourism management: New directions in contemporary tourism research. Journal of Heritage Tourism, 9(2), 166-182.

Hartmann, R. (2016). Special interest tourism to places closely associated with the victims of Nazi Germany: A Dark Heritage revisited. In P. Williams (Ed.), Special Interest Tourism (forthcoming), Wallingford, UK: CABI.

Ivry, B. (2015). When Will Anne Frank enter the public domain? Forward, October 26, 2015.

Jugendbegegnungsstaette. (2004). 10 Jahre 1994-2004. Frankfurt: Jugendbegegnungsstaette Anne Frank e.V.

Lebovic, M. (2014). A most unseemly battle over the legacy of Anne Frank. The Times of Israel, December 18, 2014.

Lee, C. A. (1999). Roses from the Earth: The biography of Anne Frank. New York: Penguin.

Lee, C. A. (2002). The hidden life of Otto Frank. New York: Collins.

Lindwer, W. (1992). The last seven months of Anne Frank. New York: Anchor Press.

Marcuse, H. (2001). Legacies of Dachau-The uses and abuses of a concentration camp, 1933-2001. New York: Cambridge University Press.

Marcuse, H. (2005). Reshaping Dachau for visitors: 1933-2000. In A. Gregory, \& R. Hartmann (Eds.), Horror and Human tragedy revisited-The management of sites of atrocities for tourism (pp. 118-148). New York: Cognizant Communication Corporation.

Marcuse, H. (2010). The afterlife of the camps. In K. Jane \& N. Wachsmann (Eds.), Concentration Camps in Nazi Germany (pp. 186-211). New York: Routledge.

Mueller, M. (1998). Anne Frank: The biography. New York: Metropolitan Books.

Mulder, D., \& Prinsen, B. (1994). Kinderen in kamp Westerbork, Westerbork Cahiers 2. Hooghalen, Drenthe: Herinnerungscentrum Kamp Westerbork.

Netherlands Institute for War Documentation. (2003). The diary of Anne Frank-The revised critical edition. New York: Doubleday.

Nsubuga, J. (2015). Anne Frank's grave may have finally been found. Retrieved from http://www.Metro.co.uk

Pearl, D. (1997). Two groups quarrel over trademark of Anne Frank Name. Wall Street Journal, LXXVIII(25), 1, 8.

Rahlwes, A. K., \& Wawra, R. (2014). Freiheitsrecht: Das Beispiel der Vorfahren und der Familie von Anne Frank (Civil liberties: The example of the ancestors and of the family of Anne Frank). Frankfurt: Bildungsstaette Anne Frank und Paedagogisches Zentrum FFM Fritz Bauer Institut \& Juedisches Museum Frankfurt, Materialheft.

Rockstroh, B. (2013). In the footsteps of Anne Frank. Retrieved from http://inspireacademics.edublogs.org/

Rosenfeld, A. (1991). Popularization and memory: The case of Anne Frank. In P. Hayes (Ed.), Lessons and legacies-The meaning of the holocaust in a changing world (pp. 243-278). Evanston, Ill.: Northwestern University Press.

Verzets Museum. (2006). Persecution and resistance in Amsterdam-Memories of World War Two: A walk from the Anne Frank House to the Dutch Resistance Museum. Amsterdam: Verzetsmuseum (Dutch Resistance Museum), with collaboration of Hans Westra (Anne Frank Stichting).

Westra, H. (2000). Anne Frank House: A museum with a story. Amsterdam: Anne Frank Stichting.

Young, J. (1999). The Anne Frank House: An accessible window to the Holocaust. Anne Frank Magazine (p. 13). 